Western University Scholarship@Western

1978

\title{
Uniform Domestic Tax Rates, Trade Distortions, and Economic Integration
}

John Whalley

Follow this and additional works at: https://ir.lib.uwo.ca/economicsresrpt

Part of the Economics Commons

Citation of this paper:

Whalley, John. "Uniform Domestic Tax Rates, Trade Distortions, and Economic Integration." Department of Economics Research Reports, 7811. London, ON: Department of Economics, University of Western Ontario (1978). 
RESEARCH REPORT 7811

UNIFORM DOMESTIC TAX RATES, TRADE DISTORTIONS, AND ECONOMIC INTEGRATION

by

John Whalley

April, 1978 
Unt form Domestic Tax Rates, Trade Distortions, and Economic Integration

\author{
John Whalley 1 \\ University of Western Ontario \\ London, Ontario \\ Canada N6A 5C2
}

- Apr11 1978

II am grateful to the Ford Foundation for support under their competition in International Economic Order during the preparation of this paper. 
The major objective usually stated for tax harmonization schemes within the wider process of economic integration is to remove distortions of intra-country trade (including factor movements) within the integrating area. This is reflected in the discussion of tax harmonization in the EEC even though additional administrative issues, such as the abolition of 'fiscal frontiers', are also present. This process is now well under way and is being used as the model for integration attempts in other areas such as the Carribean, Bast Africa, and Latin America. All member countries in the BEC now have value-added tax systems and a common structure with uniform tax rates is eventually planned. A common corporate tax system has also been tentatively agreed upon, and harmonization of excise taxes is beginning with the 'ad valorization' of specific excises.

An argument frequently heard during the tax harmonization process is that removal of distortion of trade in goods between member countries of the integrating area requires not only harmonization of indirect tax structures but also uniform tax rates across countries. ${ }^{1}$ This is the philosophy underlying integration

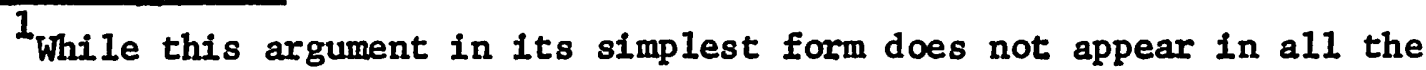
public finance literature, there is sufficient confusion that an uninitiated reader could easily draw this conclusion as prevailing opinion. Some authors in discussing uniformity of tax rates make the distinction between the case where taxes operate on a general origin or destination basis and where taxes operate on a geographically discriminatory basis, suggesting that non-distorting harmonization schemes require uniformity under the latter but not the former. In addition, some administrative arguments discussed later are stated by some as the reas on for uniformity rather than economic issues, although in such cases the economic analysis remains unclear.

An example of the uniformity proposition in its simplest form is given by the following quote from Shoup [1969] whose influence on the direction of tax harmonization at a policy leve1 has been substantial. He states [p. 645] that "Fu11 Paretian optimality,... requires that the proportional difference... between the marginal rate of transformation... and the marginal rate of substitution... be equal for any two products. This condition is violated by any 
plans for indirect taxation in the EEC, ${ }^{2}$ and surfaces in the current strategy

that harmonization of indirect taxation will involve a two-step procedure

of harmonization of structure followed by harmonization of tax rates.

In this note, two sets of propositions on the irrelevance of tax rate uni-

formity across countries for the removal of distortions of trade between integrating

countries are demonstrated for a simple international trade goods mobile factor im-

mobile general equilibrium model. ${ }^{3}$ In the case of a general tax operated on either

sales tax that is not perfectly general and perfectly uniform. To achieve this high level of optimality, the common market countries mist levy their sales taxes at a single, uniform rate."

An author drawing the distinction between general and geographically discriminatory taxes is Prest [1976] who in discussing value-added tax and income and corporate tax differences between EEC countries states ( $p .414$ ) "It is frequently argued that if any given country...collects a larger proportion of its tax revenue from VAT (and a smaller proportion from income and corporate taxes) than say, the USA, the former has an unfair advantage in international trade at any given set of exchange rates... . The fallacy here is the automatic assumption that the domestic price level is the same when a large fraction of revenue is raised from VAT as when it come from corporation tax,...the more likely result is a higher domestic price level with VAT." He goes on, however, to argue that in the event of harmonization of VAT structures among EEC countries "...if there were to be a switch to the restricted origin principle (for VAT)... the consequences would be far reaching. Not only would there have to be something like a common coverage but also something like a common rate structure."

Others are less clear on the need for tax rate uniformity. Dosser [1967] argues that differences in preferences for government intervention may dictate non-uniform rates suggesting this may be a counterweight to an argument for rate uniformity. Shibata [1967] raises some special difficulties of the restricted origin principle which are returned to below.

2 The latest document affirming this is the sixth draft directive on harmonization of value-added taxation, EBC (1973).

3

These results ignore the issue of whether monetary union (a single currency) accompanies the tax harmonization. As conventionally stated, the need for uniform tax rates is seen independently of whether or not monetary union also occurs. In the European case, uniformity of tax rates has been set as an objective well in advance of even the tentative approaches to monetary union which are now occurring. While it has been argued that tax harmonization including uniform tax rates is necessary (for Pareto optimality) before monetary union can occur, the desirability of tax rate uniformity is usually stated as being independent of the monetary regime. 
an origin or destination basis, tax rate unfformity is not necessary to remove distortions of trade between integrating countries since exchange rates (or domestic price levels) can adjust to compensate for tax rate differences. In the case of a restricted origin basis, ${ }^{4}$ non-distortion of trade can only occur where trade is 'bilaterally balanced'. This condition implies that for each country in the integrating area the value of exports equals the value of imports separately for trade with member countries and for trade with non-member countries (the more usual equilibrium balance of payments condition would apply only to all trade aggregated over both sets of countries). With bilaterally balanced trade, no distortion occurs under a restricted origin principle independent of whether uniform or non-uniform tax rates apply; ${ }^{5}$ while if trade is not bilaterally balanced, absence of distortion is impossible with either uniform or nonuniform rates.

The importance of these results is to demonstrate that the popular belief that uniform indirect tax rates are necessary to remove distortions of trade between member countries of an integrating area is incorrect. 6

${ }^{4}$ This is where an origin basis applies for transactions between member countries of the integrating area and the destination basis for trade between member countries and non-member countries.

5 This is subject to certain administrative problems raised by Shibata [1967], and explained below.

${ }^{6}$ In the case of harmonization of income and corporate taxation, issues of factor mobility ignored here must be addressed. Discussion of tax harmonization in the presence of factor mobility appears in Dosser [1967]. 
Uniformity as a goal should be accepted on administrative rather than economic arguments, and the conflicts that uniformity create with national autonomy correspondingly evaluated. While the result on the irrelevance of uniformity for a general rather than geographically discriminating tax are not new (even if stated unclearly in the literature), the results for the restricted origin case do appear to be. As each individual country's trade will typically not satisfy the required bilateral balance condition, the impossibility of achieving a non-distorting harmonized tax scheme under the restricted origin principle is a result of substantial importance for the EEC. ${ }^{7}$ This principle corresponds to that under which harmonized valueadded tax systems and rates are currently planned.

II. THE IRRELEVANCB OF TAX RATB UNIFORMITY UNDER A GENERAL ORIGIN OR DESTINATION BASED TAX 8

The lack of necessity for tax rate uniformity under either a general origin or destination based indirect tax to remove distortions of trade among member countries of an integrating area may be easily seen in a simple two-country, two-commodity general equilibrium model. Consider a twocountry world where each country produces a single good from a single productive factor. Let $x_{1}$ and $x_{2}$ be the outputs of goods 1 and 2 produced in countries 1 and 2 , respectively. If there is constant (unitary) marginal productivity of labour, the production functions are given by the equation

7 In spite of the claims of US and other trade officials, the restricted origin principle is not a deliberate trade restricting policy on the part of the EEC. It is seen as an advantageous administrative system of operating a non-distorting harmonized tax system. Trade policy objectives are instead to be fulfilled by the common external tariff.

${ }^{8}$ The geographically discriminatory restricted origin principle is discussed in the next section. The integration scheme for VAT proposed for EEC member countries adheres to a restricted rather than general origin principle and so the analysis of this section is not directly applicable in this case. 


$$
\mathrm{X}_{1}=\mathrm{L}_{1}, \mathrm{X}_{2}=\mathrm{L}_{2}
$$

where $I_{1}$ and $L_{2}$ are the amounts of labour available in each country. $x_{1}^{2}$ and $x_{2}^{1}$ respectively denote the demands for good 1 in country 2 , and for good 2 in country 1 , where the relative prices of the two goods in domestic currencies of each country determine demands. These items therefore refer to country $1^{\prime}$ 's exports ( $2^{\prime} \mathrm{s}$ imports) and country $1^{\prime} \mathrm{s}$ imports (2's exports). ${ }^{9} \quad P_{1}$ and $P_{2}$ are the producer prices of the two goods in domestic currency and $w_{1}$ and $w_{2}$ are the domestic currency wage rates. Under perfect competition

$$
P_{1} X_{1}=w_{1} I_{1}, P_{2} X_{2}=w_{2} I_{2},
$$

and as each country must in zero trade balance in equilibrium,

$$
P_{1} x_{1}^{2}=e_{2}^{1} p_{2} x_{2}^{1}
$$

where $e_{2}^{1}$ is the exchange rate giving the price of a unit of country $1^{\prime}$ 's currency in terms of that of country 2 's.

Suppose that in this simple model in the absence of taxation an equilibrium is achieved defined by $\overline{\mathrm{P}}_{1}, \overline{\mathrm{P}}_{2}, \mathrm{e}_{2}^{-1}, \overline{\mathrm{w}}_{1}, \overline{\mathrm{w}}_{2}$ and associated values $\overrightarrow{\mathrm{x}}_{1}, \overrightarrow{\mathrm{x}}_{2}^{1}$. Given the absence of any government intervention this equilibrium will be Pareto optimal. A non-distorting tax harmonization scheme is one that leaves

9 The differences between the tax regimes discussed here are in the tax treatments of foreign trade transactions. Thus the simplification of one good being produced in each country with complete specialization by each does not prevent the generalization of the propositions developed to more complex situations. For the broadly based taxes analyzed, extensions to many goods produced in each country follow directly. 
the real characteristics of the equilibrium unchanged. The same quantities $\overline{\mathrm{x}}_{1}^{2}$ and $\overline{\mathrm{x}}_{2}$ satisfy the zero trade balance condition and relative consumer prices in domestic currencies are unchanged from the no-tax situation.

The lack of necessity for uniformity of indirect tax rates in economic integration applies under both fixed and flexible exchange rate regimes. ${ }^{10}$ The revenue effects of the tax are removed in the analysis that follows by assuming that there is one consumer in each country who receives the tax revenue as a lump sum transfer.

We begin by considering the case of a broadly based sales tax operated on an origin basis at rate $t_{1}$ in country 1 and $t_{2}$ in country 2 . In this case (2) remains unchanged, but (3) becomes

$$
P_{1}\left(1+t_{1}\right) x_{1}^{2}=e_{2}^{1} P_{2}\left(1+t_{2}\right) x_{2}^{1}
$$

Since (2) does not change, an equilibrium with unchanged values of $\bar{x}_{1}^{2}, \bar{x}_{2}^{1}$ wil1 be achieved if $P_{1}=\bar{P}_{1}, P_{2}=\bar{P}_{2}$, e $=\left(1+t_{1}\right) \bar{e} /\left(1+t_{2}\right), w_{1}=\bar{w}_{1}$, and $w_{2}=\bar{w}_{2}$. 'The exhcnage rate will thus adjust such that gross of tax relative prices in domestic currencies in both countries are unchanged and the balance of trade condition (4) will be satisfied. Thus, if an origin based broadly based tax operates in all countries forming an economic union, the removal of barriers to trade does not require uniformity of tax rates as frequently stated. While tax rate uniformity does not distort trade flows it is not necessary. 11

10

This reflects a classical result in international trade theory that the real characteristics of a long-run equilibrium are independent of the exchange rate regime. Under flexible exchange rates the rates themselves adjust, while under fixed rates domestic price levels adjust.

${ }^{11}$ And thus if taxes fill different revenue raising functions in different countries, the implication is that there is no clear reason to interfere unnecessarily with this by requiring tax rate uniformity in the tax harmonization process. 
and $\bar{x}_{2}^{1}$ can be achieved in the fixed exchange rate case if $P_{1}=\bar{p}_{1} /\left(1+t_{1}\right)$, $P_{2}=\bar{p}^{2} /\left(1+t_{2}\right), e=\bar{e}, w_{1}=\bar{w}_{1} /\left(1+t_{1}\right)$, and $w_{2}=\bar{w}_{2} /\left(1+t_{2}\right)$. In 1ong-run equilibrium the exchange rate regime makes no difference to the result that tax rate uniformity is unnecessary.

The same proposition on the irrelevance of tax rate uniformity can also be demonstrated for the case of a destination based sales tax. Once again, the same real equilibrium conditions will prevall independent of domestic tax rates.

If a destination based retail sales tax is introduced in both countries in place of the origin based tax, equations (2) and (3) remain unchanged. Thus for unchanged domestic currency relative prices (gross of tax) and the trade balance condition to hold $P_{1}=\bar{P}_{1} /\left(1+t_{1}\right), P_{2}=\bar{P}_{2} /\left(1+t_{2}\right)$, $e=\bar{e}\left(1+t_{2}\right) /\left(1+t_{1}\right), w=\bar{w}_{1} /\left(1+t_{1}\right), w_{2}=\bar{w}_{2} /\left(1+t_{2}\right)$. In the case of a fixed exchange rate regime, $P_{1}=\bar{p}_{1}, P_{2}=\bar{P}_{2}$, $e=\bar{e}, w_{1}=\bar{w}_{1}, w_{2}=\bar{w}_{2}$.

similar results can also be demonstrated for cases of more than two countries and where combinations of bases operate across countries (i.e., some countries operate origin based taxes and others destination based taxes). In all these cases, for a general tax the removal of distortions to trade among member countries of an integrating area does not require uniform tax rates. 
III. TAX RATE UNIFORMITY AND TRADE DISTORTION UNDER

\section{A RESTRICTED ORIGIN PRINCIPIE ${ }^{12}$}

Where a geographically discriminatory basis is used for a general

tax the simple propositions of Section II break down but not in the way

that it is implied in either academic literature and in the policy documents produced by EEC agencies. Under a restricted origin principle, the origin principle is used for trade between members of an integrating area (EEC member countries) while the destination basis is used for trade between member countries and non-member countries (non-EEC countries). ${ }^{13}$ Under such a principle it can be demonstrated that any tax rate, either uniform or non-uniform, will usually distort trade in the sense that trade flows between member countries of an integrating area cannot be the same as in the non-tax situation. The only case where no distortion of trade occurs is where trade is 'bilaterally balanced' in a no tax situation. Bilateral balance implies that the value of exports equals the value of imports separately for trade with other member countries of the integrating area and for trade with non-member countries. Thus uniform tax rates are no more $11 k e l y$ than non-uniform tax rates to achieve an absence

12 The term 'restricted origin principle' is due to Shibata [1967] and it does not appear in the earlier EEC report (the 'Neumark' Report [1963]) in which this principle was recommended.

${ }^{13}$ In the EEC case, the origin principle for intra-EEC trade is justified by the desire to abolish 'fiscal frontiers: (i.e., the rebating of taxes on exports and the taxing of imports at the border). This attempt to abolish fiscal frontiers partly explains the adoption of the value-added tax as the target of tax harmonization in the EEC since it was argued that a retail sales tax on an origin basis is impossible to administer. The destination basis for extra-EEC trade is justified by the desire to adjust prices for taxation components. In the EEC view, taxes are rebated on EEC exports for them to compete abroad and placed on imports for EEC products to compete in EEC markets. This latter argument uses the fallacy that a move from the origin to the destination basis will affect real equilibrium conditions. 
of distortions under the restricted origin principle, ${ }^{14}$ and are, save in exceptional circumstances, trade distorting. A similar set of results applies under a restricted destination principle.

This argument may be made as follows. Suppose we consider three countries, 1, 2, 3, each as before producing a single good. Let the total outputs of these goods be $x_{1}, x_{2}, x_{3} \cdot x_{1}^{2}, x_{1}^{3}$ represent demand by countries 2 and 3 for good 1 , and $x_{2}^{1}, x_{2}^{3}, x_{3}^{1}, x_{3}^{2}$ have similar interpretations with the subscript representing goods and the superscript countries. Producer prices of goods in domestic currencies are denoted by $P_{1}, P_{2}, P_{3}$, and exchange rates by $e_{2}^{1}, e_{3}^{1}$, and $e_{3}^{2}$.

\section{4} Shibata [1967] raises the administrative difficulty, that with a restricted origin principle imports into any member country of an integrating area from outside the area will enter through the lowest tax rate country of those in the area for re-export to higher tax countries. By this device, the lowest of the country tax rates will be paid when the destination based tax is charged and no tax will apply for re-export to higher tax rate member countries since the origin principle will apply. Shibata terms this problem one of trade deflection and highlights the revenue loss to the higher tax rate countries.

This problem is similar to the issue raised with free trade areas that without a common external tariff, goods will enter the trade area in the country where tariffs are lowest and will then travel free of tariff to other countries. Shibata suggests a 'common external tax' to deal with the problem. A further alternative would be to operate "rules of destination' such that goods entering the area would be required to declare eventual destination within the area. The latter, however, requires trade monitoring at borders of higher tax rate countries to enforce the rules.

Even with the common external tax, different tax rates could be set for the origin based taxes on area internal trade. The common external tax as a destination based tax would however be a discriminatory tax in such circumstances since differential tax rates would be charged on goods consumed in each country.

The discussion in the text treats these problems as administrative aspects of the tax harmonization issue; and the result remains that whether or not 'trade deflection' occurs, if trade is not bilaterally balanced the restricted oxigin principle cannot produce a non-distorted trading pattern. 
Under the no tax situation, the equilibrium balance of trade conditions for the three countries are given by

$$
\begin{aligned}
& P_{1}\left(x_{1}^{2}+x_{1}^{3}\right)=e_{2}^{1} P_{2} x_{2}^{1}+e_{3}^{1} P_{3} x_{3}^{1} \\
& P_{2}\left(x_{2}^{1}+x_{2}^{3}\right)=P_{1} x_{1}^{2} / e_{2}^{1}+e_{3}^{2} P_{3} x_{3}^{2} \\
& P_{3}\left(x_{3}^{1}+x_{3}^{2}\right)=P_{1} x_{1}^{3} / e_{3}^{1}+P_{2} x_{2}^{3} / e_{3}^{2}
\end{aligned}
$$

Now we suppose that countries 1 and 2 form an economic union in which they each operate a sales tax at rates $t_{1}$ and $t_{2}$ respectively on a restricted origin principle. For trade between 1 and 2 the origin principle applies, and for trade involving 3 the destination principle applies. It is assumed that no tax operates in country 3 , but such a tax can be introduced into the analysis with no loss of generality. Under the restricted origin principle, the equilibrium balance of trade conditions for the three countries are

$$
\begin{aligned}
& P_{1} X_{1}^{2}\left(1+t_{1}\right)+P_{1} X_{1}^{3}=e_{2}^{1} P_{2} x_{2}^{1}\left(1+t_{2}\right)+e_{3}^{1} P_{3} x_{3}^{1} \\
& P_{2} X_{2}^{1}\left(1+t_{2}\right)+P_{2} X_{2}^{3}=\left(P_{1} X_{1}^{2} / e_{2}^{1}\right)\left(1+t_{1}\right)+e_{3}^{2} P_{3} X_{3}^{2} \\
& P_{3} X_{3}^{1}+P_{3} X_{3}^{2}=P_{1} X_{1}^{3} / e_{3}^{1}+P_{2} X_{2}^{3} / e_{3}^{2}
\end{aligned}
$$

For the taxes operated under the restricted origin principle to have no trade distorting effect, it must be true that new prices and exchange rates are such that (6) holds with the same values of $\bar{x}_{1}^{2}, \bar{x}_{1}^{3}, \bar{x}_{2}^{1}, \bar{x}_{2}^{3}, \bar{x}_{3}^{1}, \bar{x}_{3}^{2}$, as in the no tax situation and that relative gross of tax prices in domestic currencies are unchanged in each country from the no tax situation.

Using bars above variables to denote their equilibrium value in the no tax situation, unchanged relative commodity prices in each country under the restricted origin tax require that 


$$
\frac{P_{1}\left(1+t_{1}\right)}{e_{2}^{1} P_{2}\left(1+t_{2}\right)}=\frac{P_{1}}{e_{2}^{-1} \bar{P}_{2}} ; \frac{P_{2}}{e_{3}^{2} P_{3}}=\frac{\bar{P}_{2}}{\bar{e}_{3}^{2} \bar{P}_{3}} ; \frac{P_{1}}{e_{3}^{1} P_{3}}=\frac{\bar{P}_{1}}{-e_{3}^{1} P_{3}}
$$

If the balance of trade conditions (6) also hold, by substitution

$$
\begin{aligned}
& \left(1+t_{1}\right) \bar{P}_{1} \bar{x}_{1}^{2}+\overline{\mathrm{P}}_{1} \overline{\mathrm{X}}_{1}^{3}=\left(1+\mathrm{t}_{1}\right) \mathrm{e}_{2}^{-1} \overline{\mathrm{P}}_{2} \overline{\mathrm{x}}_{2}^{-1}+\mathrm{e}_{3}^{-1} \overline{\mathrm{P}}_{3} \overline{\mathrm{x}}_{3} \\
& \left(1+t_{2}\right) \bar{P}_{2} \bar{x}_{2}^{1}+\bar{P}_{2} \bar{x}_{2}^{3}=\left(1+t_{2}\right) \bar{P}_{1} \bar{x}_{1}^{2} / \bar{e}_{2}^{1}+\bar{e}_{3}^{2} \bar{P}_{3} \bar{x}_{3}^{2} \\
& \overline{\mathrm{p}}_{3} \overline{\mathrm{x}}_{3}^{1}+\overline{\mathrm{p}}_{3} \overline{\mathrm{x}}_{3}^{2}=\overline{\mathrm{p}}_{1} \overline{\mathrm{x}}_{1}^{3} / \overline{\mathrm{e}}_{3}^{-1}+\overline{\mathrm{p}}_{2} \overline{\mathrm{x}}_{2}^{3} / \overline{\mathrm{e}}_{3}^{2}
\end{aligned}
$$

Given that (5) holds for the no tax situation, the first equations of (8) can only be satisfied if $\quad \bar{P}_{1} \bar{X}_{1}^{2}=e_{2}^{-1} \bar{P}_{2} \bar{X}_{2}^{-1}$ (i.e., a situation of bilaterally balanced trade). If this situation occurs then uniformity of tax rates is not required. If, however, trade is not bilaterally balanced in this way it is impossible to introduce a system of taxes on a restricted origin principle which does not change real trade flows from the no tax situation.

\section{CONCLUSION}

In this note the argument that uniform tax rates across integrating countries are necessary to remove trade distortions has been re-examined. It has been shown in a simple goods mobile, factor immobile, international trade model that uniformity of tax rates is not necessary with a general origin or destination based tax since exchange rates can adjust. Under a restricted origin basis, it has been shown that absence of distortion is only possible if trade is bilaterally balanced, in which case uniform or non-uniform rates across countries will serve equally well. As trade for any country will not typically satisfy the bilateral balance condition, the impossibility of achieving a non-distorted harmonized tax scheme under the restricted origin principle is especially important for current harmonization proposals in the ERC. 
IV. BIBLIOGRAPHY

Dosser, D. [1967] "Economic Analysis of Tax Harmonization" in (ed.)

C. S. Shoup, Fiscal Harmonization in Common Markets, vol. I,

Theory (New York: Columbia University Press).

E.E.C. [1973] Sixth Draft Directive on Harmonization of Turnover Taxes,

Brussels.

"Neumark Report" [1963] "Report of the Fiscal and Financial Committee" in The EEC Reports on Tax Harmonization, International Bureau of Fiscal Documentation.

Prest, A. R. [1976] Public Finance in Theory and Practice (5th edition), (London: Wiedenfeld and Nicholson).

Shibata, H. [1967] "The Theory of Bconomic Unions: A Comparative Analysis of Customs Unions, Free Trade Areas, and Tax Unions" in (ed.) C. S. Shoup Fiscal Harmonization in Common Markets, vo1. I, Theory (New York: Columbia University Press).

Shoup, C. S. [1969] Public Finance (London: Wiedenfeld and Nicholson). 